\title{
Renewable Energy Gathers Steam in South Africa
}

David Richard Walwyn* ${ }^{1}$, Alan Colin Brent ${ }^{2}$

$*^{1}$ Corresponding Author

Email: david.walwyn@up.ac.za

Mail Address: Graduate School of Technology Management, University of Pretoria, Private Bag X20, Hatfield, Pretoria 0028, South Africa

Physical Address: Room 2-18, Engineering 2 Building, Hatfield Campus, University of Pretoria, Pretoria, South Africa

${ }^{2}$ Email: acb@sun.ac.za

Mail Address: Department of Industrial Engineering, and the Centre for Renewable and Sustainable Energy Studies, Stellenbosch University, Private Bag X1, Matieland, 7602, South Africa.

Physical Address: Room A601, Department of Industrial Engineering, and the Centre for Renewable and Sustainable Energy Studies, Stellenbosch University, Corner of Banhoek and Joubert Streets, Stellenbosch, 7600 , South Africa.

\begin{abstract}
South Africa's Renewable Energy Independent Power Producers Procurement Programme (the REI4P) is an extensive initiative to install $17.8 \mathrm{GW}$ of electricity generation capacity from renewables - wind, solar, biomass, biogas and hydropower - over the period 2012 to 2030. Although at the outset the REI4P seemed an expensive option, designed only to deflect criticism of South Africa's high carbon footprint and excessive dependence on coal-based electricity generation, the escalating costs of the latter, the rapidly falling costs of photovoltaic and wind power, and the increasingly competitive bidding process of the REI4P have changed this prospect. At the conclusion of round three, the weighted cost of energy has reached a $23 \%$ discount to the cost of new coal-based generation and a $28 \%$ discount to global renewable energy prices. The bidders' commitments to local employment creation have similarly increased from 11 to 18 jobs/MW. The programme is now well placed to deliver on a broad range of objectives, including regional development and black economic empowerment. However, maximum benefit from the REI4P will not be secured without some revision to aspects of the bidding and procurement process. More specifically, the local content provisions need to be tightened to drive higher levels of local manufacturing.
\end{abstract}

\section{Keywords}

Renewable energy; learning curve; localisation; South Africa; energy policy 


\section{Introduction}

The Renewable Energy Independent Power Producers Procurement Programme (known as the REI4P) is a large infrastructure plan designed to reduce South Africa's carbon emissions, thereby addressing concerns over its present dependence on nuclear and coal as primary energy sources [1]. At the time of its launch, the programme made little economic sense given that its weighted cost of electricity was predicted to be more than three times the cost of coal-based electricity generation. This premonition was confirmed by the results of the REI4P's round one, for which the average quoted cost was $\$ 248 / \mathrm{MWh}$ vs. an estimated $\$ 71 / \mathrm{MWh}$ for conventional coal-based power generation at the time of the bidding ${ }^{1}$.

Furthermore, previous localisation initiatives in South Africa, such as the Defence Industrial Participation Programme, have been poorly implemented [2, 3]. Although the present policy environment appears to firmly support the principles of innovation-led growth and the Beijing Consensus [4], the country's track record in being able to use major capital expenditure projects to support domestic economic growth and manufacturing has suffered from inadequate controls and monitoring capacity. It is therefore important that initiatives such as the REI4P are continuously assessed and publicly discussed in respect of delivery vs. key objectives.

Fortunately recent developments appear to have altered the cost/benefit balance of the REI4P. Rising costs for the construction of two new coal-based power stations - Medupi and Kusile - and falling costs of power from wind and solar, suggest that REI4P could reach grid parity in 2016 and become cost neutral by 2017. Furthermore, it is possible that the programme could deliver a broad range of other benefits in addition to the obvious favourable impact on carbon release and the mitigation of climate change.

This paper provides an overview of the REI4P together with a detailed discussion of the three bidding rounds, the weighted average cost of power, and the prospects for grid parity in the short term. Global benchmarks for renewable energy initiatives are developed (Section 2) and these metrics are used as performance targets to rate the present performance of the REI4P, including its overall expected cost and intended benefits (Section 3 ). The prospects of the programme achieving its three key objectives of job creation, enterprise development and increased local manufacturing based on a comparison to the global norms are discussed in Section 4. Finally, the conclusions of the analysis and the implications for renewable energy policy in South Africa and elsewhere are presented in Section 5.

\section{Global Benchmarks for Renewable Energy}

\subsection{Cost of Renewable Energy}

Contrary to cost profiles of most fossil fuels and particularly coal, the cost of electricity generation from renewables has fallen dramatically over the last decade and is predicted to continue this steep decline until at least 2030 [5]. The levelised cost of electricity (LCOE)

\footnotetext{
${ }^{1}$ These figures are based on published data for Round One procurement costs and the 2012 exchange rate of R8.5/\$. More detail is provided in Section 3.
} 
from photovoltaic panels, geothermal sources and onshore wind generators is close to, or below, grid parity in many countries and essentially equal to the equivalent greenfield cost of electricity from either conventional coal or nuclear technologies (see Figure 1).

Figure 1. Total cost of generation by technology

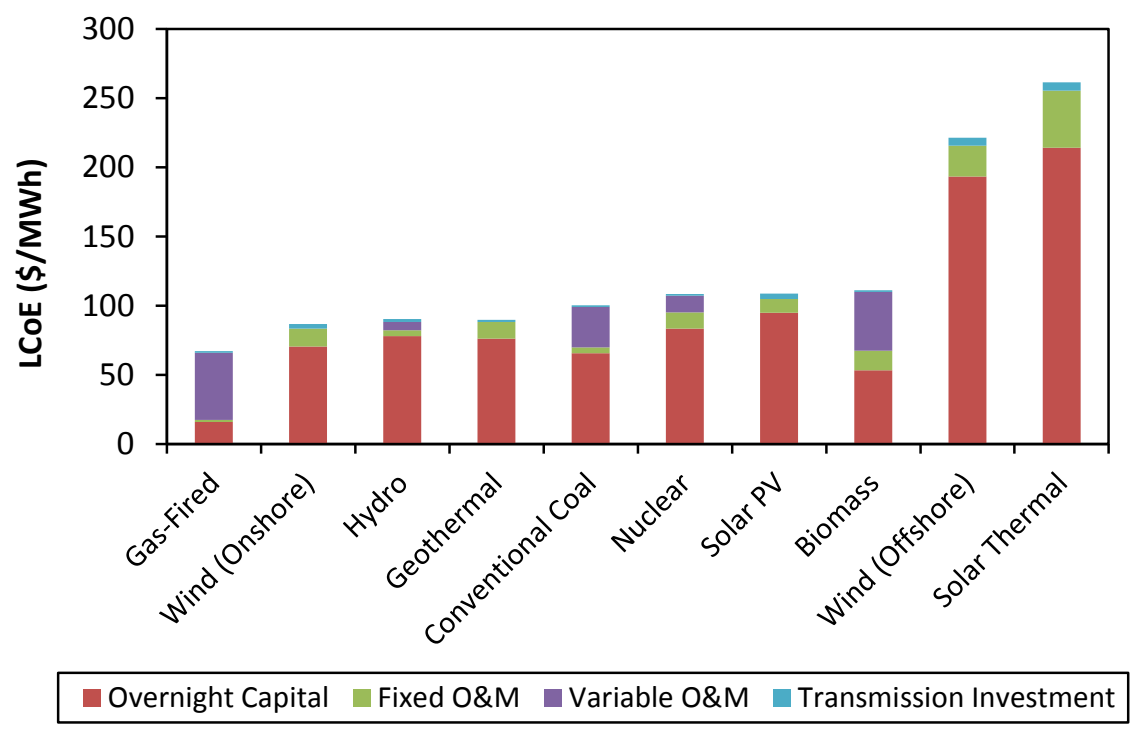

Source: U.S. Energy Information Administration [46]

This ranking of electricity generation technologies is a new phenomenon; even as recently as 2012, large-scale comparative surveys have placed renewable technologies as more expensive options compared to nuclear and fossil fuels [6-8]. The LCOE from solar photovoltaic (PV) installations have decreased dramatically, with the prices of PV modules falling by $60 \%$ over the period January 2011 to December $2012[9,10]$. This sharp decrease in prices is expected to continue (see Figure 2) and has become known in the industry as Swanson's Law, which states that the "price of solar photovoltaic modules tends to drop $20 \%$ for every doubling of cumulative shipped volume" [11].

Figure 2. PV module selling prices decrease with cumulative production

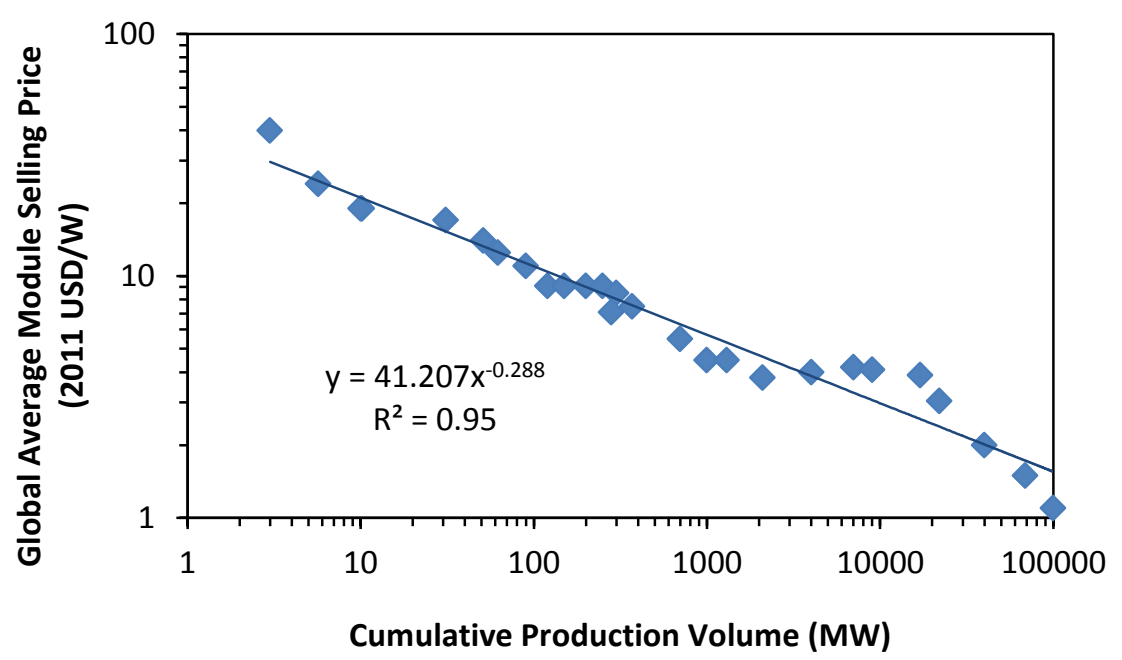

Source: IRENA [47] 
Similarly, the LCOE of wind power is competitive even against gas-fired generation with some of the lowest-cost producers being in the range of 40 to $50 \$ / \mathrm{MW}$ [9]. Installed costs of wind turbines are about $\$ 1,800$ to $\$ 2,200 / \mathrm{kW}$ in most countries with the exception of China where costs are $50 \%$ cheaper [9]. The equivalent cost of PV panels in India, Germany and China is reported to be about $\$ 1,720, \$ 2,008$ and $\$ 2,160 / \mathrm{kW}$ respectively [8].

LCOE values tend to be highly site specific and as a consequence a direct comparison between the various technologies is complex, and even misleading. For instance, the cost can depend heavily on firstly the quality of the resource (average wind strength or solar insolation) and secondly on local financing costs.

With respect to the quality of the resource, the LCOE of wind power scales proportionally in response to wind quality, and this quality various greatly across South Africa (see Figure 3). Solar power is similar; a concentrating solar power plant in the best locations of South Africa - more than $2400 \mathrm{kWh} / \mathrm{m}^{2}$ - will generate at least $20 \%$ more power for the same capital investment than locations with a solar resource similar to where the plants in Spain are operational $-2000 \mathrm{kWh} / \mathrm{m}^{2}$ (see Figure 4).

Figure 3. Best wind resource quality areas in South Africa

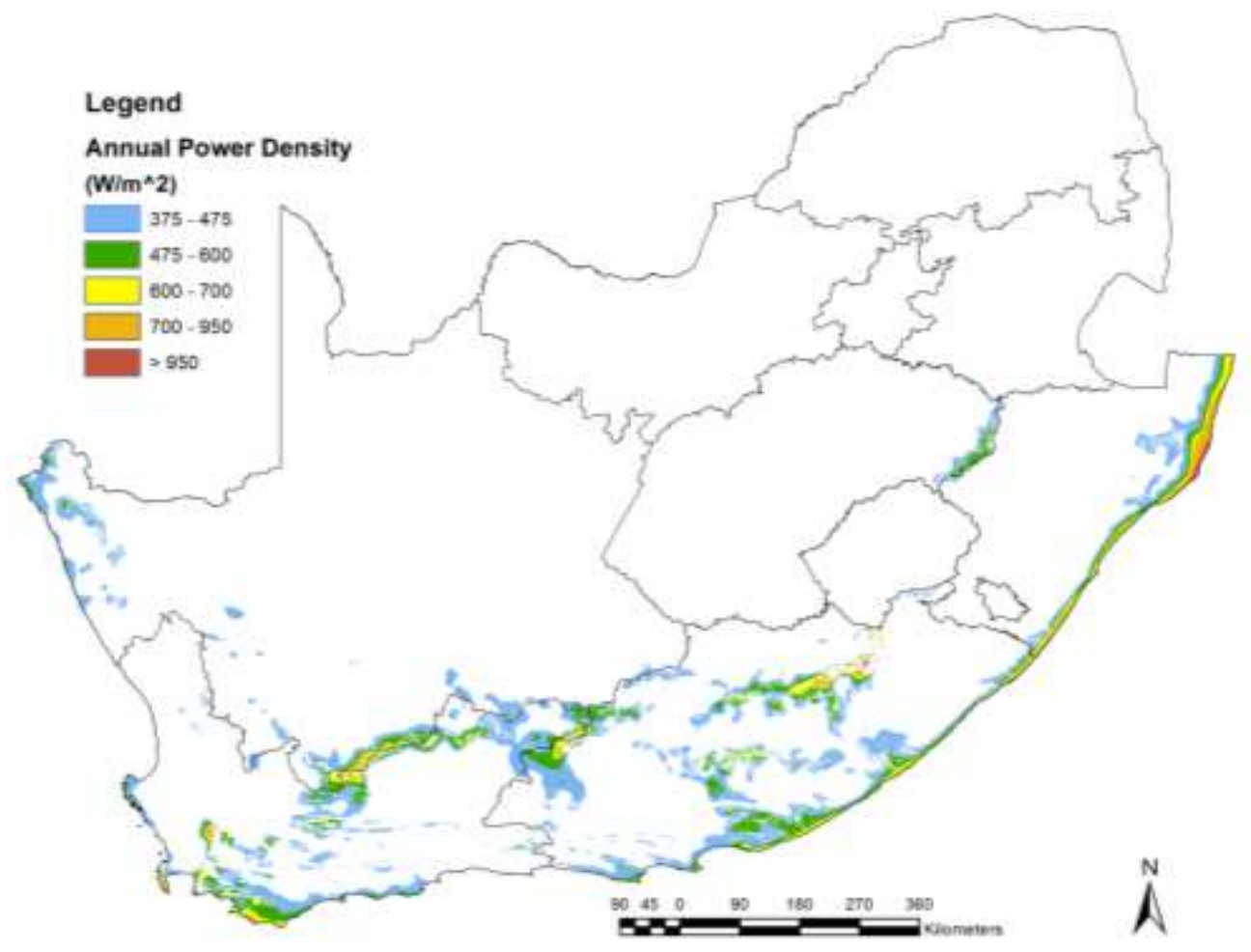


Figure 4. Solar resource quality across South Africa

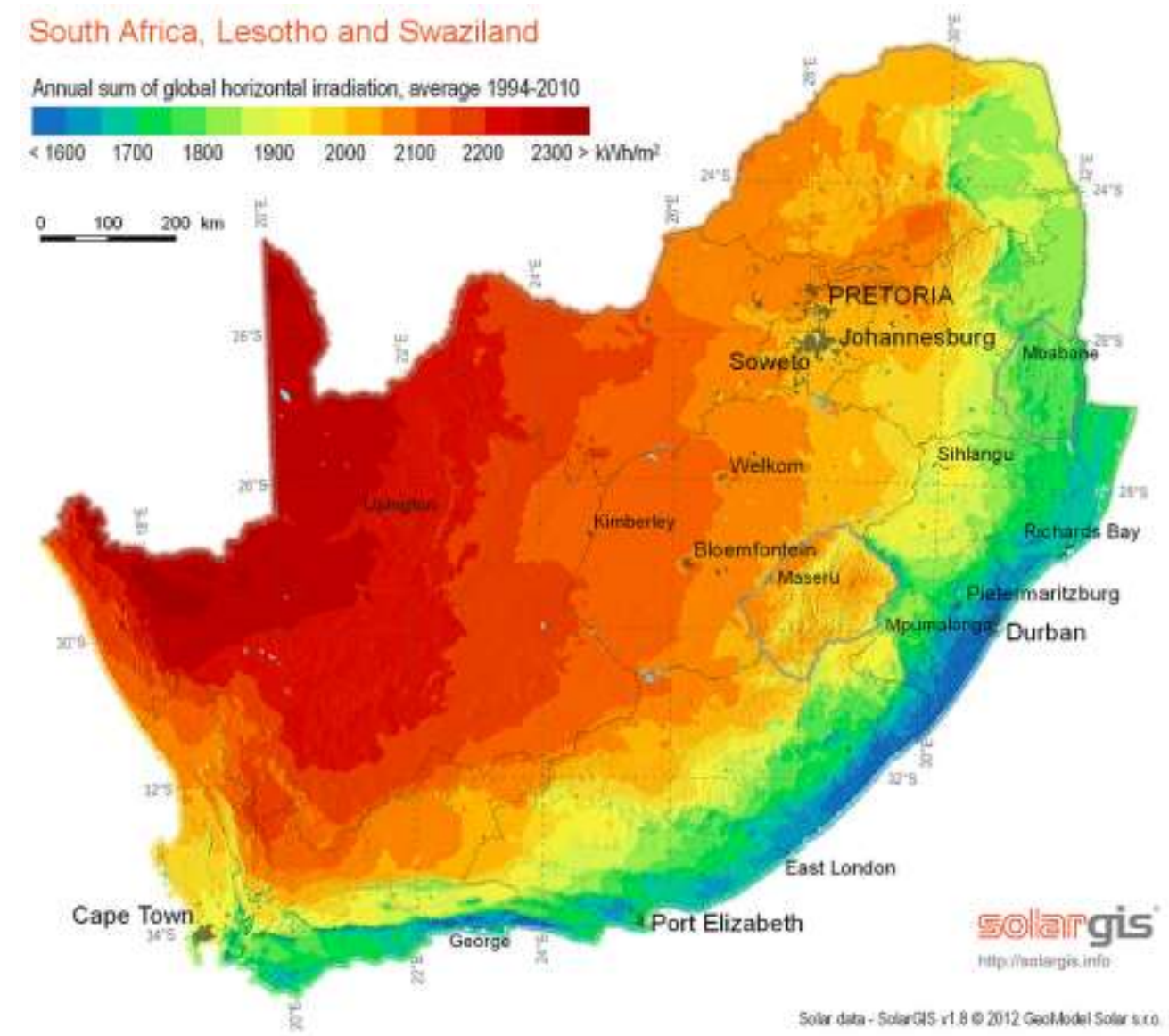

In terms of local financing costs, the LCOE from wind power, for example, is about $60 \%$ higher for an increase in the cost of capital from 5.5\% to 14.5\% [9]. Most renewable energy technologies (RETs), with the exception of biomass, are by implication capital intensive (see Figure 5), since the raw material is essential without cost, and as a consequence financing charges can significantly influence investment decisions. Developers of renewable energy projects require stable procurement contracts at guaranteed prices and off-take structures within low cost capital structures in order to submit competitive proposals. 
Figure 5. Relative proportions of cost factors to total generation cost

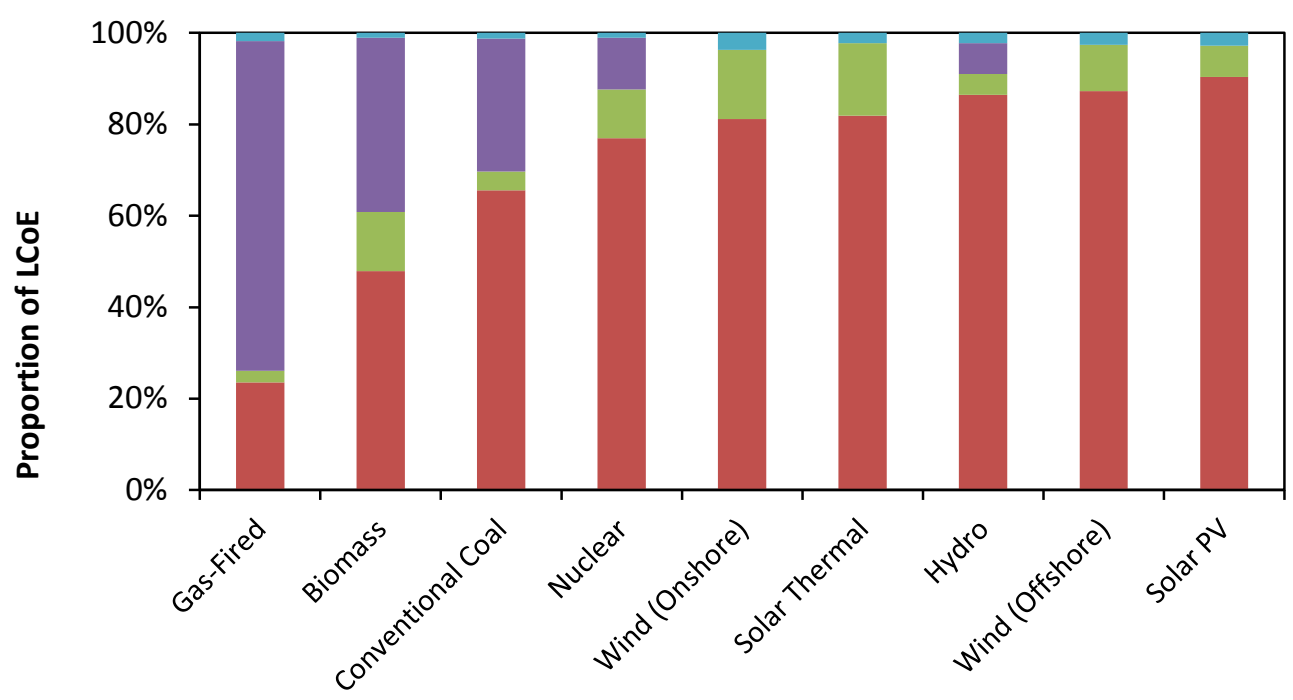

Overnight Capital

Fixed O\&M

Variable O\&M

- Transmission Investment

Source: U.S. Energy Information Administration [46]

It is noted that the LCOE values in Figure 5 are proportional to the total costs; the actual costs are shown in Figure 6. Wind and solar thermal are the most expensive, and gas-fired power stations and onshore wind the least expensive.

\section{Figure 6. Actual costs of generation}

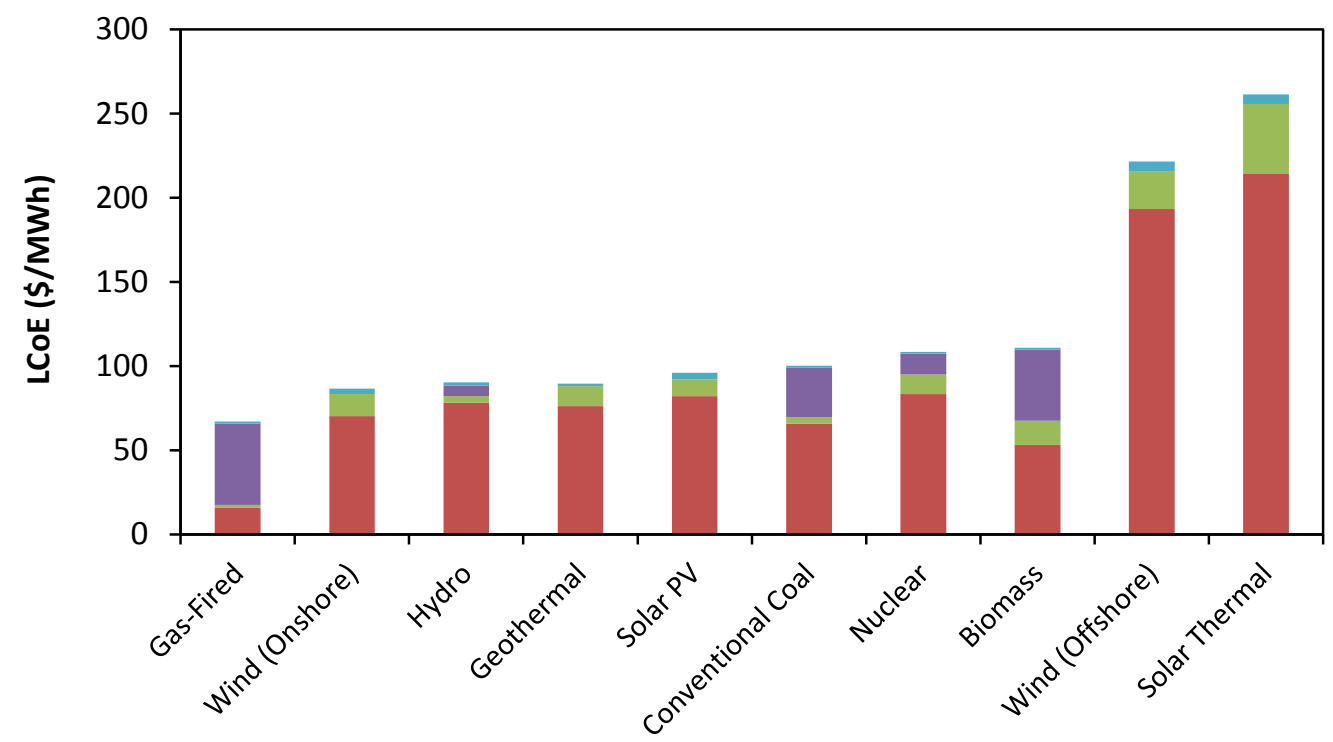

- Overnight Capital

Fixed O\&M

Variable O\&M

Transmission Investment

Source: U.S. Energy Information Administration [46] 


\subsection{Learning Curves to Predict Renewable Prices}

Learning curves have been employed as a generalised methodology to predict the future cost of products or services based on the historical trajectories. The assumption of the predictions is that for new technologies or products prices fall over time as a consequence of several factors including increased competition, innovation, 'learning by doing' and 'economies of scale'. This fall in price is modelled by the Pearl curve as follows $[12,13]$ :

$$
y=\frac{L}{1+a \cdot e^{-b i}}
$$

where $y$ is the present 'technology performance', $L$ is the expected limit of performance, and $i$ is the cumulative investment (usually R\&D) or time, and $a$ and $b$ are the coefficients that determine the shape of the $S$ curve.

For $i<<\ln (a) / b$ or $y<<$ this equation is often simplified to the classic power law

$$
y=K \cdot i^{c}
$$

which for the purposes of this analysis on PV module prices can be expressed as follows:

$$
(\text { Price })_{2}=(\text { Price })_{1} \times\left(\frac{\text { Capacity }_{2}}{\text { Capacit }_{1}}\right)^{c}
$$

where $c$ is the power relationship and suffix 1 and 2 refer to prices and cumulative production capacities at times 1 and 2 respectively. Often the exponent $c$ is captured as the learning rate (LR), which is the proportional reduction in price for a doubling in manufacturing capacity ${ }^{2}$, or:

$$
L R=1-2^{c}
$$

For example, learning rates for cost of PV modules as a function of installed capacity have been calculated at $20 \%$ to $25 \%$ depending on the times periods [14]. In this study, a learning rate of $18 \%$ has been calculate over the period 1979 to 2012 , but a much higher rate of $31 \%$ over the more recent period of 2006 to 2013.

Predictions as to the future of PV prices are hazardous given the dynamic nature of these markets and the recent performance, which seems to have exceeded expectations. Using data from the period 2002 to 2013, the Pearl parameters were estimated by using a least squares (sum of errors) algorithm, giving a technology limit $(L)$ of about $1.25 \mathrm{~W} / \$$ or $0.8 \$ / \mathrm{W}$. A similar exercise using the learning rates estimates that PV module prices could call as low as $0.7 \$ / W$ by the end of 2020 (see Figure 7) [15].

\footnotetext{
${ }^{2}$ Note that this relationship only applies over the linear part of a technology S curve only.
} 
Figure 7. Actual and predicted PV module prices from 2002 to 2020

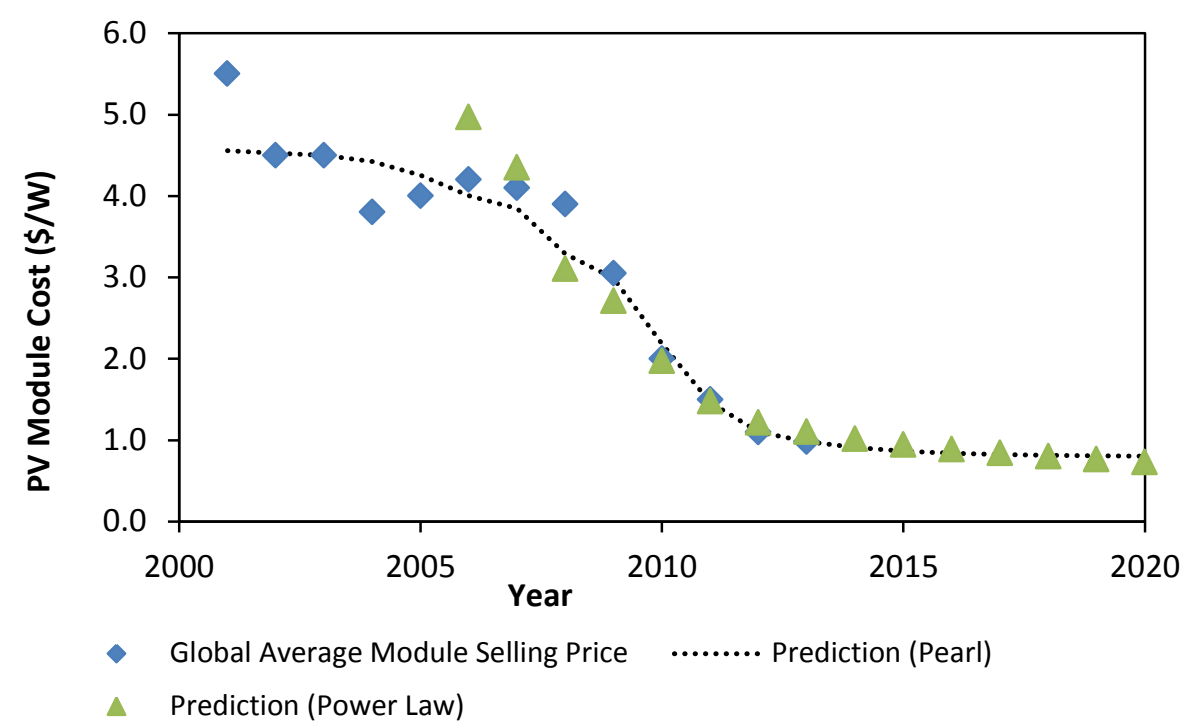

The conversion of PV module prices to installed overnight costs for PV facilities and finally to PV power cost depends on various assumptions such as transmission charges, operating and maintenance charges, and PV modules as a proportion of total capital costs. In this study, the capital portion of the LCOE has been calculated by using the single year cost of capital, which is about $20 \%$ per annum in South Africa. The remaining components have been calculated by assuming an inflation-linked escalation for the cost of transmission, operations and maintenance, and variable costs. These estimates have then been used to predict the future LCOE for PV, based on both the power law and learning curve estimates, and compared to the predicted cost of power from coal-based generation (see Figure 8). This comparison confirms previous predictions, namely that the cost of PV power will fall below the cost of power from coal by the beginning of 2015 , if the present learning rates on PV

Figure 8. Actual and predicted LCOE costs for PV power

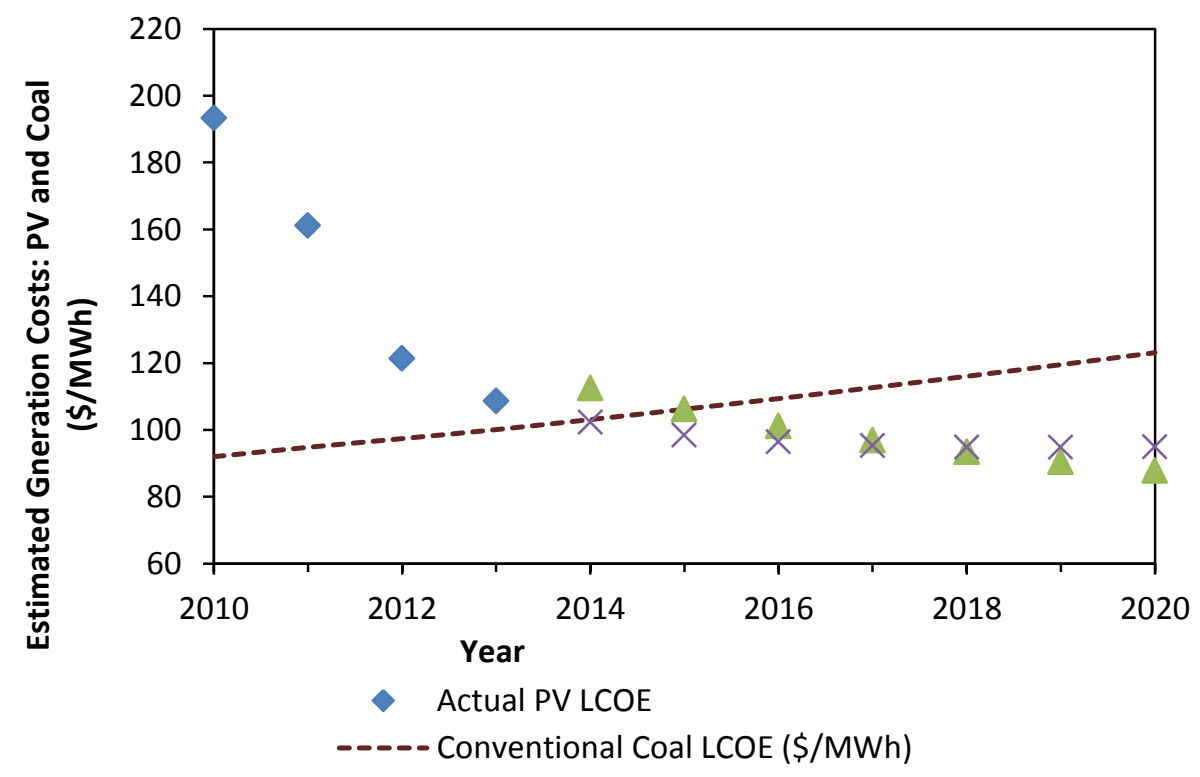

Source: PVinsights [48] and own calculations 
modules are maintained. This is an important and significant finding for the industry, and one that has not yet been fully acknowledged in national energy policies.

\subsection{Employment in Renewables}

RETs have significant employment potential $[16,17]$, as shown in Table 1, although these jobs have become highly localised as some countries have been more successful than others in growing sustainable sectors.

Table 1. Direct and indirect jobs in renewable energy technologies (excluding solar water heating)

\begin{tabular}{|l|c|c|c|c|c|}
\hline \multirow{2}{*}{ Sub-Sector } & \multirow{2}{*}{$\begin{array}{c}\text { Global Average } \\
\text { (Jobs/MW) }\end{array}$} & \multicolumn{3}{|c|}{ Number of Direct and Indirect Jobs (Thousands) } \\
\cline { 3 - 6 } & 1.9 & Global & China & Germany & India \\
\hline Biofuels & 7.7 & 1,379 & 24 & 23 & 35 \\
\hline Solar PV & 1.8 & 753 & 266 & 57 & 58 \\
\hline Biomass & 1.7 & 753 & 267 & 118 & 48 \\
\hline Wind Power & 6.3 & 266 & 90 & 50 & 85 \\
\hline Biogas & 2.2 & 180 & & 14 & \\
\hline Geothermal & 2.5 & 109 & & 7 & 12 \\
\hline Hydropower (small) & 2.0 & 53 & & 2 & \\
\hline Solar Thermal (CSP) & & $\mathbf{4 , 8 5 3}$ & $\mathbf{9 4 7}$ & $\mathbf{3 5 9}$ & $\mathbf{3 5 0}$ \\
\hline Total & & & & & \\
\hline
\end{tabular}

Source: REN21 [17] and Wei [50]

The literature data for PV-related jobs is unclear, with some sources claiming that an average of 30 jobs per peak MW installed capacity are created, spread between operations (1\%), manufacturing (14\%), module assembly (36\%) and construction/installation (49\%) [18]. Excluding installation, distribution and integration, more than $54 \%$ of the manufacturing jobs are located in module assembly [19], equivalent to about 11 jobs per peak MW. On the other hand, labour costs for this portion of the value chain account for $6 \%$ of the overall costs [20], suggesting a high ratio of employment creation to cost and consequently a potential opportunity for low-cost employment creation [19].

More conservative estimates report the PV-associated jobs at 8 to 10 jobs/MW. One of the sources of discrepancy may be the assumption in respect of the construction jobs. Given that less than $5 \%$ of the total jobs are in longer-term employment (such as financing, operations and maintenance, research and development), these assumptions will heavily influence the final estimate. For this analysis, a lower value of 10 jobs/MW has been adopted on the basis that in the medium term the manufacturing and construction sector will stabilise at $30 \%$ of total installed capacity ( $10 \%$ refurbishment and $20 \%$ expansion).

\subsection{Key Success Factors for the Renewable Energy Sector}

Finally, in this section the key success factors for a renewable energy sector are briefly discussed. It is considered that the sustained success of a renewable energy industry, defined as its establishment and profitable operations with high levels of job creation and 
supply of products at competitive prices, requires attention to a range of factors within national energy markets. Although local market demand is vital, this is not the only important policy instrument; it is essential to also introduce suitable supply-side measures (such as support for R\&D, training and the development of standards), and to ensure conditions for healthy competition alongside viable, clear and long-term government commitment to supporting the sector $[16,21]$.

Table 2. South Africa's compliance with the key success factors for a domestic renewable energy sector

\begin{tabular}{|c|c|c|c|}
\hline \multicolumn{2}{|r|}{ Key Success Factor } & \multirow{2}{*}{$\frac{\text { Compliance }}{\mathrm{Y}}$} & \multirow{2}{*}{$\begin{array}{l}\text { Comment on South Africa's Compliance } \\
\text { Policy is clearly stated in the IRP } 2010 \text { to } 2030 \text { and } \\
\text { REI4P (detailed tender documents). }\end{array}$} \\
\hline \multirow{4}{*}{$\frac{\text { ̀o }}{\grave{0}}$} & $\begin{array}{l}\text { Clear and consistent } \\
\text { government policy }\end{array}$ & & \\
\hline & $\begin{array}{l}\text { Transparent policy } \\
\text { implementation }\end{array}$ & $\mathrm{N}$ & $\begin{array}{l}\text { There is limited public information on the } \\
\text { implementation of REI4P; some agencies are } \\
\text { performing dual functions with clear conflict of } \\
\text { interest. }\end{array}$ \\
\hline & Mix of policy instruments & Y & $\begin{array}{l}\text { Specific demand side measures (competitive bidding } \\
\text { and supply contracts) and generalised supply side } \\
\text { incentives (R\&D, human capital). }\end{array}$ \\
\hline & Enforcement of policies & Partly & $\begin{array}{l}\text { Lack of compliance with aspects of local content and } \\
\text { other components. }\end{array}$ \\
\hline \multirow{3}{*}{ 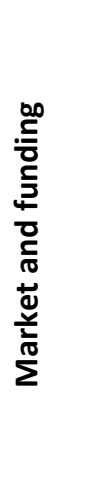 } & $\begin{array}{l}\text { Balance between stability } \\
\text { and adaptability }\end{array}$ & $\mathrm{N}$ & $\begin{array}{l}\text { Although investors require stability, especially in terms } \\
\text { of price, policies should allow for degression of prices } \\
\text { to avoid the risk of overcompensating developers; the } \\
\text { tender allows for inflation-adjusted pricing but no } \\
\text { degression [38]. }\end{array}$ \\
\hline & Access to affordable capital & Partly & $\begin{array}{l}\text { South Africa's cost of capital generally higher than } \\
\text { most developed countries; moreover the industry's } \\
\text { reliance on the Industrial Development Corporation is } \\
\text { considered a weakness. }\end{array}$ \\
\hline & Public R\&D funding for RET & Partly & $\begin{array}{l}\text { More R\&D funding will be required specifically for } \\
\text { RETs if a stronger local industry is planned. }\end{array}$ \\
\hline \multirow{4}{*}{ 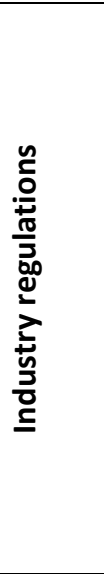 } & $\begin{array}{l}\text { Regulations to support } \\
\text { investment }\end{array}$ & $\mathrm{Y}$ & $\begin{array}{l}\text { The programme has managed to achieve high overall } \\
\text { coordination between government departments in } \\
\text { establishing the necessary regulatory framework. }\end{array}$ \\
\hline & Local content requirements & Partly & $\begin{array}{l}\text { Local content rules and requirements need tightening } \\
\text { to ensure higher levels of localisation and job creation. }\end{array}$ \\
\hline & $\begin{array}{l}\text { Demand-pull and supply- } \\
\text { push }\end{array}$ & Y & $\begin{array}{l}\text { Independent power producers are offered a } \\
\text { guaranteed market for power supplied to the national } \\
\text { grid; further incentives to switch to the most } \\
\text { economical means of electricity generation will be } \\
\text { required. }\end{array}$ \\
\hline & Industry standards & Y & $\begin{array}{l}\text { Required for consistency in local content, etc. South } \\
\text { Africa has quality standards in certain areas such as } \\
\text { solar water heating. }\end{array}$ \\
\hline \multirow{2}{*}{ 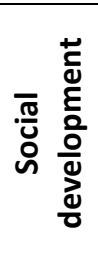 } & $\begin{array}{l}\text { Government coordinated } \\
\text { training in renewable } \\
\text { energy technologies }\end{array}$ & $\mathrm{N}$ & $\begin{array}{l}\text { Human capital development is adequate in } \\
\text { environmental sciences but lacking in more practical } \\
\text { training at the technology level. }\end{array}$ \\
\hline & $\begin{array}{l}\text { Stakeholder involvement } \\
\text { (local participation and } \\
\text { ownership) }\end{array}$ & Partly & $\begin{array}{l}\text { Local communities are mostly disappointed that there } \\
\text { are not more local jobs; on the positive side, there is a } \\
\text { diverse geographical spread of the IPPs. }\end{array}$ \\
\hline
\end{tabular}

Source: IRENA [51] and Mulcahy [19] 
A summary of the key success factors for a renewable energy sector is shown in Table 2. The balance between demand-pull and R\&D support as a means of accelerating technological change and the establishment of new industries is an important consideration for countries in their policy structure for renewable energy industries. Whilst the evidence indicates the importance for both to exist simultaneously, governments tend to favour demand-pull policy measures as a consequence of the more immediate market response to such stimulants. However, a case study of wind power has concluded that demand-pull has had limited success in inducing non-incremental technical change and that governments should be wary of pursuing such policies in the absence of direct R\&D support [22].

\section{A Programme Evaluation of the REI4P}

\subsection{Overview of the REI4P}

The REI4P is an ambitious initiative to install $17.8 \mathrm{GW}$ of electrical power in South Africa from renewable sources - wind, solar, biomass, biogas and hydropower - by 2030. According to Haffajee [23], the three main policy drivers for the REI4P were a reduction in carbon in intensity - carbon dioxide emissions from $912 \mathrm{~g} / \mathrm{kWh}$ to $600 \mathrm{~g} / \mathrm{kWh}$; additional generation capacity - to alleviate immediate shortage; and opportunities for economic development.

Inventories of greenhouse gas emissions in South Africa have highlighted the high emissions profile of the country although there is some disagreement as to the exact level of emission, with estimates between 470,000 and $550,000 \mathrm{Gg}$ of carbon dioxide-equivalent [24]. The potential to use renewable energy as a means of reducing the carbon footprint, and simultaneously reducing the present energy shortfall, has already been noted. In particular the widespread adoption of solar water heating has been recommended [25]. However the latter has been slow to penetrate the electrical water heating market and remains at an insignificant level (1 to $2 \%$ ) [25]; it is clear that a utility-scale intervention is required if the present deadlock is to be overcome.

A similar conclusion has been reached for other countries in the sub-Saharan region, including Kenya, Nigeria and Ghana [26, 27], and a number of recommendations have been suggested in order to boost the use of renewable energy, such as policy reform, government support, access to the national grid for independent power producers, low-cost financing, increased public awareness and education [26]. The same issues have surfaced in other developing countries including Malaysia [28], India [29] and Algeria [30]. Many different policy models and instruments for the stimulation of renewable energy generation have been adopted and reviewed in the literature such as Germany [31], Greece [32], China [33, 34] and Malaysia [35]. Procurement models varying from feed-in-tariffs (FIT) to competitive tenders have been implemented with different levels of success.

Although South Africa initially considered a feed-in-tariff mechanism to support the growth of grid-connected renewable energy, the REI4P is a competitive tender or auction-basedtariff (ABT) system with clearly defined rounds of bid submission, adjudication and financial closure [36]. The adjudication process consists of two steps; the first being a screening process in which all bids are required to meet certain minimum requirements in a number of areas including environmental and technical compliance with the bid documents, and the 
second step being the formal evaluation of the bid against a multiple of measurement areas [37] including economic development and black economic empowerment.

Targets for local economic development were defined in the initial policy documents that formed the basis for the REI4P's implementation [38], and listed job creation; local content aimed at increasing local manufacturing; rural development, and especially the inclusion of previously disadvantaged regions in the economy; local community participation and socioeconomic development; skills development and education; enterprise development through promotion of new entrants to the renewable energy industry; and participation of previously disadvantaged citizens in the industrial economy.

The potential impact of the REI4P on local job creation and economic development was not an unreasonable expectation given the experience of other countries including China and Germany, as shown in Table 1 . Moreover, both objectives are of critical importance to the future of the country, given persistently high levels of unemployment (>25\%) and low rates of economic growth (about 3\% p.a.) [39]. Youth unemployment in particular is a major problem; for black youth, it is estimated that the unemployment rate is $65 \%$ [39]. The issue has been highlighted in South Africa's National Development Plan 2030 (NDP 2030), which has set the following specific employment objectives [40]:

- a fall in the strict unemployment rate from $25 \%$ to $14 \%$ in 2020 to $6 \%$ by 2030 ;

- a rise in the labour force participation rate from $54 \%$ in 2010 to $65 \%$; and

- 11 million additional jobs by 2030.

Whilst the achievement of the objectives of the NDP 2030 will require progress on a broad front, the potential contribution of an emerging renewable energy sector to the growth of the South African manufacturing sector and the alleviation of its employment crisis provided a necessary incentive for its government to support the REI4P. However, as in all public projects embracing multiple objectives, these incentives have had to stand alongside other objectives including the necessity of providing immediate relief to the country's present energy shortfall [41]. In the following section, the REI4P's progress against its key targets for the period 2011 to 2013 is described and reviewed.

\subsection{Implementation of REI4P from 2011 to 2013}

As of January 2014, bidding on the first three rounds has closed and the results have been announced (see Table 3). The industry anticipates that the request for proposals will be reissued in March of each year (with round four being issued in 2014), followed by closure in August, until the year 2027 by which time the full $17.8 \mathrm{GW}$ will have been allocated. At this stage only $3.92 \mathrm{GW}$ have been allocated, of which about $750 \mathrm{MW}$ has become operational. 
Table 3. Summary of REI4P bidding results

\begin{tabular}{|c|c|c|c|c|c|c|c|c|}
\hline \multirow{2}{*}{ Round } & \multirow{2}{*}{$\begin{array}{c}\text { Bid Closing } \\
\text { Date }\end{array}$} & \multirow{2}{*}{$\begin{array}{c}\text { Planned } \\
\text { Purchase } \\
\text { (MW) }\end{array}$} & \multicolumn{2}{|c|}{ Bids Received } & \multicolumn{2}{|c|}{ Bids Preferred } & \multirow{2}{*}{$\begin{array}{l}\text { Value } \\
\text { (\$ mill) }\end{array}$} & \multirow{2}{*}{$\begin{array}{c}\text { Weighted } \\
\text { Average } \\
\text { Capital } \\
\text { Cost } \\
\text { (\$/MW) }\end{array}$} \\
\hline & & & No & MW & No & MW & & \\
\hline One & 04-Nov-11 & 1,416 & 53 & 2,128 & 28 & 1,416 & 46,026 & 32.52 \\
\hline Two & 05-Mar-12 & 1,044 & 79 & 3,255 & 19 & 1,044 & 28,059 & 26.88 \\
\hline Three & 19-Aug-13 & 1,456 & 93 & 6,023 & 17 & 1,456 & 33,810 & 23.22 \\
\hline Total & & 3,915 & 225 & 11,406 & 64 & 3,915 & 144,723 & \\
\hline
\end{tabular}

Source: Eberhard [52] and own data

The power allocations and price caps for each technology and bidding round are shown in Table 4. The latter appear to have been based on international LCOE prices and in the first two rounds, the bid prices were mostly at or close to the price cap, with the exception of onshore wind, which was bid at $78 \%$ of the cap. However, by round three all major technologies were bid at significant discounts to the price caps (see Section 3.3).

Table 4. Summary of REI4P technology-based power targets

\begin{tabular}{|l|c|c|c|c|c|c|}
\hline \multirow{2}{*}{ Technology } & \multicolumn{3}{|c|}{ Power Allocations (MW) } & \multicolumn{3}{c|}{ Price Caps (\$/MWh) } \\
\cline { 2 - 7 } & One & Two & Three & One & Two & Three \\
\hline Solar PV & 631.5 & 417.0 & 401.3 & 285 & 174 & 140 \\
\hline Onshore Wind & 634.0 & 562.6 & 653.6 & 115 & 115 & 110 \\
\hline Small Hydro & 0.0 & 14.3 & 120.7 & 103 & 103 & 106 \\
\hline CSP & 150.0 & 50.0 & 200.0 & 345 & 285 & 165 \\
\hline Biomass & 0.0 & 0.0 & 60.0 & 107 & 110 & 140 \\
\hline Biogas & 0.0 & 0.0 & 12.5 & 90 & 90 & 90 \\
\hline Landfill Gas & 0.0 & 0.0 & 25.0 & 84 & 90 & 94 \\
\hline Total & $\mathbf{1 , 4 1 5 . 5}$ & $\mathbf{1 , 0 4 3 . 9}$ & $\mathbf{1 , 4 7 3 . 1}$ & & & $\mathbf{2 1 5}$ \\
\hline Weighted Average & & & & 147 & $\mathbf{1 2 7}$ \\
\hline
\end{tabular}

The process of bidding is expensive and complex (see the Appendix), with the cost to the developer being in the region of $\$ 2$ million per bid, depending on the size of the contract, with the bulk of the fees due to legal costs and raising of the bid bond; the latter is a deposit submitted at the time of bidding, which is refundable unless the bidder defaults on the bid commitments.

A key issue is the impact of the required probability factor $\left(P_{50}\right.$ Vs. $\left.P_{90}\right)$ on the final cost. In the calculation of the final bid price - selling price of power to the utility in $\$ / \mathrm{MWh}-$ it is necessary to estimate the expected capacity utilisation whose value is partly influenced by the degree of certainty required by the developer's financial partners; the higher the level of certainty, the lower the estimated capacity utilisation and hence the higher the bid price. In general, most financial institutions require the use of $P_{90}$, whereas a developer using inhouse or balance sheet funding would use the $P_{50}$. The difference between the two factors 
relates to the degree of certainty in the capacity utilisation, with $\mathrm{P}_{90}$ being a higher level of certainty.

The impact of this requirement is illustrated by considering a solar PV plant, which has been designed at a nameplate peak capacity of $100 \mathrm{MW}$, installed at $\$ 1 / \mathrm{W}$. The actual peak capacity delivered to the grid - through a local substation - will be somewhat less than this figure due to on-site power requirements and losses in the collection and inversion of the generated power. Assuming a 5\% loss, the rated capacity of the plant, as stated in the bid documents, will be $95 \mathrm{MW}$. The capacity utilisation of single-axis tracking PV panels will be about $30 \%$ on average, also referred to the $P_{50}$ value. As a consequence, the expected energy output of the plant will be $95 *$ total hours per year.

However, if much of the capital required for the project must be funded though bank loans, these institutions stipulate the use of the $P_{90}$ value, which would be the normal value of $30 \%$ less 1.3 standard deviations of the expected variance in solar power for the selected site. Assuming a standard deviation of $4 \%$ [42], this requirement reduces the capacity factor by a further $10 \%$. In other words, the capacity factor is now $27 \%$, adding a further 5 to $6 \%$ onto the bid price (see Table 5).

Table 5. Impact of $P_{90}$ Vs. $P_{50}$ on bid price

\begin{tabular}{|l|c|c|c|}
\hline Item & Units & P50 & P90 \\
\hline Total Finance Charges & \$ mill/year & \multicolumn{2}{|c|}{27} \\
\hline Operating Hours & h/year & 8,322 & 7,889 \\
\hline Average Capacity & $\%$ & $29 \%$ & $27 \%$ \\
\hline Power Output & MWh & 249,660 & 236,678 \\
\hline Bid Price & \$MWh & 108 & 114 \\
\hline
\end{tabular}

It is noted that the calculations in Table 5 include single year capital, fixed, variable and transmission costs, and assume a required return on investment of $20 \%$ per year, equivalent to an actual return on investment of about $17 \%$, based on the local currency (South African Rands). It has been reported that the real returns to equity in round one were close to the $17 \%$, but these were reduced in round two to $13 \%$ as a consequence of higher levels of competition in the bidding process [37]. In the same table, the operating hours have been calculated assuming 347 days of sunshine for the P50 value and 329 days for P90; the latter value has been estimated based on $95 \%$ resource availability less 1.3 standard deviations (4\%) due to the higher specification for P90.

\subsection{Costs of Renewable Energy from REI4P}

Bid prices for the procurement of renewable energy from the various submissions are shown in Table 6, from which it is apparent that:

- the weighted average cost of electrical power from RETs has declined progressively since the launch of the programme from 211 to $84 \$ / M W h$;

- the differential between the price cap and the average purchase price has widened from $2 \%$ below the price cap to $34 \%$ (on a weighted average basis); and 
- the REI4P purchase price has declined relative to the weighted average LCOE from its initial value of $124 \%$ of the LCOE to $72 \%$ (in other words, the local price is now more, not less, competitive than the USA cost).

Table 6. REI4P bid prices relative to USA LCOE

\begin{tabular}{|l|c|c|c|c|c|c|}
\hline \multirow{2}{*}{ Technology } & \multicolumn{3}{|c|}{ Average Cost (\$/MWh) } & \multicolumn{2}{c|}{ Estimated Cost from USA LCOE (\$/MWh) } \\
\cline { 2 - 7 } & One & Two & Three & One (2011) & Two (2013) & Three (2014) \\
\hline Solar PV & 276 & 165 & 88 & 211 & 144 & 114 \\
\hline Wind & 114 & 90 & 66 & 97 & 87 & 86 \\
\hline Small Hydro & N/A & 90 & N/A & 86 & 90 & 90 \\
\hline CSP & 345 & 262 & 146 & 312 & 262 & 250 \\
\hline Other (Bio) & N/A & 111 & 104 & 111 & 111 & 113 \\
\hline Weighted Cost & $\mathbf{2 1 1}$ & $\mathbf{1 2 8}$ & $\mathbf{8 4}$ & $\mathbf{1 7 1}$ & $\mathbf{1 1 8}$ & $\mathbf{1 1 8}$ \\
\hline
\end{tabular}

Source: U.S. Energy Information Administration [46]; U.S. Energy Information Administration [53]; and own data.

The steep decline in REI4P bid prices is shown in Figure 9. Many reasons have been stated for the steep decline, although unofficial. For example, original equipment manufacturers having access to stock not taken up in other parts of the world.

Figure 9. REI4P bid prices more competitive in the recent rounds
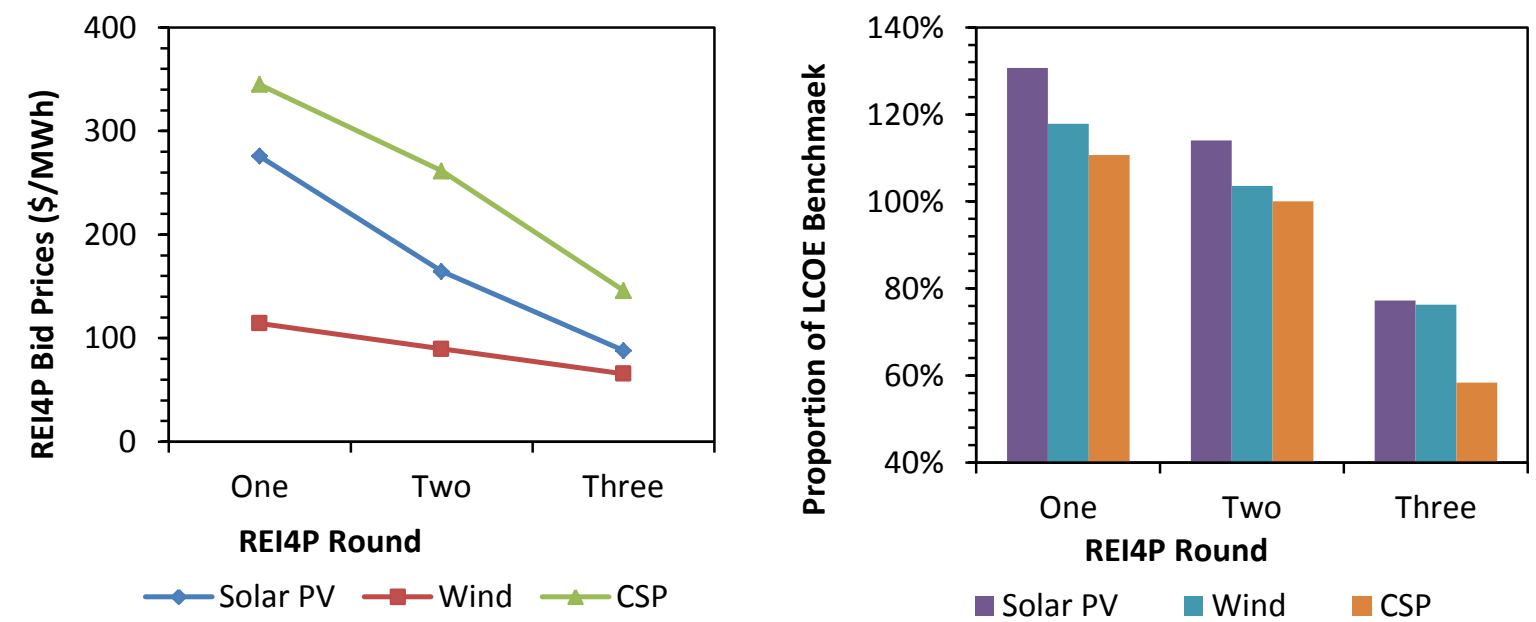

There has been some controversy about the cost of REI4P to Eskom - the national utility and, in this case, the client for the REI4P energy, with Eskom claiming that the actual cost would be $\$ 198 / \mathrm{MWh}$ and the National Energy Regulator of South Africa (NERSA) ruling in $2013 / 14$ that only a portion of these costs would be allowed. In this study, the procurement costs have been further revised to allow for entry of the rounds two and three bidders, on the assumption of the bid prices as either published or estimated and a two-year implementation period. 
A comparison of the NERSA ruling on the average allowable Eskom tariffs (labelled as the 'Eskom Average Price'), the Eskom/NERSA REI4P application costs, the estimated costs for REI4P energy from this study and the cost of Eskom power from new coal-based power stations (namely Medupi and Kusile and labelled as 'Eskom New Cost) is shown in Figure 10. Although the present REI4P cost is more than three times the average allowable Eskom tariff, and probably at least double the eventual cost of power from the two new coal-based power stations of Medupi and Kusile, the future comparison are highly favourable, with the REI4P cost being lower than the coal-based equivalent by 2016 (see Figure 10).

Figure 10. Cost projections for conventional coal vs. REI4P

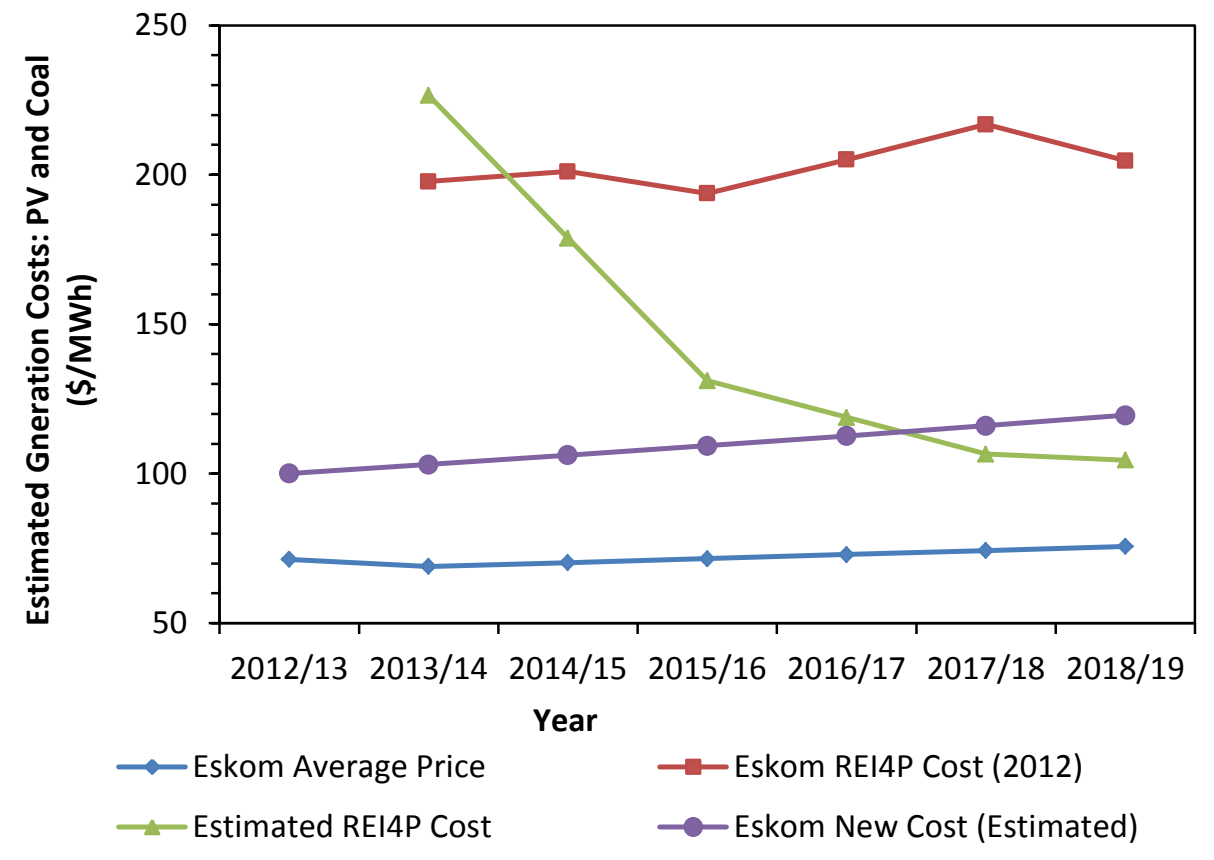

Source: Price information has been obtained from own data; NERSA [49]; and U.S. Energy Information Administration [46].

It is possible to calculate the additional cost from the REI4P to the South African consumer using the information shown in Figure 10 (the difference between Eskom New Cost and the Estimated REI4P Cost) and an estimated power output. The additional cost is computed at $\$ 31 / \mathrm{MWh}$, which is equivalent to a premium of $3.5 \%$ on the 2014 allowable tariff. Over the period 2013 to 2030, it is also estimated that the first two rounds of REI4P will increase electricity purchase by about $\$ 19$ million and $\$ 3$ million respectively but round three will result in a saving of $\$ 5$ million relative to the cost of power from a new coal-based generator (see Table 7). In other words, although rounds one and two have resulted in higher costs, the subsequent rounds will reduce the cost of power for South African consumers, especially if the future bidding rounds focus on the more cost-effective technologies only. 
Table 7. The estimated price premium of electricity through REI4P

\begin{tabular}{|l|c|c|c|c|c|}
\hline \multirow{2}{*}{ Technology } & \multirow{2}{*}{$\begin{array}{c}\text { Capacity } \\
\text { Utilisation }\end{array}$} & \multicolumn{2}{|c|}{ Generated Electricity (MWh/year) } & \multirow{2}{*}{$\begin{array}{c}\text { Premium } \\
\text { (\$ mill/year) }\end{array}$} \\
\cline { 3 - 5 } & & One & Two & Three & \\
\hline Solar PV & $30 \%$ & 827,518 & 546,437 & 570,024 & 163 \\
\hline Wind & $30 \%$ & 830,794 & 737,169 & $1,031,285$ & -48 \\
\hline Small Hydro & $90 \%$ & 0 & 56,334 & 0 & -1 \\
\hline CSP & $25 \%$ & 163,800 & 54,600 & 218,400 & 56 \\
\hline Other (Bio) & $80 \%$ & 0 & 0 & 118,810 & -1 \\
\hline Average Cost & & $\mathbf{1 , 8 2 2 , 1 1 1}$ & $\mathbf{1 , 3 9 4 , 5 4 0}$ & $\mathbf{1 , 9 3 8 , 5 1 8}$ & $\mathbf{1 6 9}$ \\
\hline
\end{tabular}

\subsection{Employment and Manufacturing}

REI4P adopted local content as a measure of the manufacturing spin-offs from the independent power producers, where according to SATS 1286:2011 [43] the local content of a product is the tender price less the value of imported content, expressed as a percentage (provided that local manufacture does take place) as follows:

$$
L C=\left(1-\frac{x}{y}\right) * 100
$$

where

$\mathrm{x} \quad$ is the imported content in Rand

$\mathrm{y} \quad$ is the bid price in Rand excluding value added tax (VAT)

Prices referred to in the determination of $x$ must be converted to South African Rand by using the exchange rate published by the South African Reserve Bank (SARB) at 12:00 on the date of advertisement of the bid. The REI4P bid documents specified both minimum (45\%) and target (65\%) local content levels, with points being awarded in the adjudication process according to the specified level within the actual bid.

In support of this local content requirement, a number of policy instruments are available in South Africa to reduce the risk of inward investments including a tax rebate and favourable financing rates from the Industrial Development Corporation [19]. Nevertheless, the response of the bidders to the localisation policies has been disappointing in the early stages of the REI4P. According to Mulcahy [19], of the 27 PV projects in the first two rounds, only 4 projects are using locally manufactured panels, equivalent to less than $5 \%$ of the overall PV power. Altogether about 300 jobs have been created or about 3 jobs per MW vs. the international norm of 10 jobs per MW (see Section 2.3), and the local contents have been reported at $25 \%$ and $41 \%$ for rounds one and two respectively. Moreover, there has been some intentional manipulation of the local content whereby bidders have been able to claim high local content without having to purchase any of the major components (inverters, panels or support structures) from local manufacturers [19].

The disappointing response to the local content targets in the first two rounds has been partly rectified in round three, for which a local content of $47 \%$ has been reported [44]. 
Furthermore, the number of jobs per MW (operation and construction) has increased by $60 \%$ from 11 to 18 (see Table 8), which is more than double the global average and well above the benchmark levels. It is noted, however, that the figures in Table 8 represent bid commitments as opposed to actual jobs created; it is not known at this stage whether these obligations have been fulfilled or whether there will be significant shortfalls. Certainly the data from Mulcahy [19] seem to suggest that the bidders mostly fail to reach their stated targets.

Table 8. Job creation commitments in the REI4P

\begin{tabular}{|c|c|c|c|c|c|}
\hline \multirow[b]{2}{*}{ Technology } & \multirow{2}{*}{$\begin{array}{c}\text { Global } \\
\text { Benchmark } \\
\text { (Jobs/MW) }\end{array}$} & \multicolumn{3}{|c|}{ REI4P (Operation Jobs/MW) } & \multirow{2}{*}{$\begin{array}{c}\text { Total Jobs } \\
\text { (Operation \& } \\
\text { Construction) }\end{array}$} \\
\hline & & $\begin{array}{l}\text { Round } \\
\text { One }\end{array}$ & $\begin{array}{l}\text { Round } \\
\text { Two }\end{array}$ & $\begin{array}{l}\text { Round } \\
\text { Three }\end{array}$ & \\
\hline Solar PV & 7.7 & 9.7 & 9.1 & 17.3 & 24,209 \\
\hline Onshore Wind & 1.7 & 3.9 & 4.0 & 10.8 & 19,414 \\
\hline CSP & 2.0 & 9.2 & 23.6 & 8.7 & 10,423 \\
\hline Average (Operation) & & 7.0 & 6.9 & 12.5 & \\
\hline $\begin{array}{l}\text { Average (Operation \& } \\
\text { Construction) }\end{array}$ & & 11.3 & 11.9 & 18.0 & \\
\hline
\end{tabular}

Source: Haffajee [23]

\section{Discussion}

Round one of the REI4P was certainly a slow start. Limited competition between the bidders, exemplified by a bid success rate of $53 \%$, resulted in high prices relative to the price caps and international benchmarks ( $98 \%$ and $124 \%$ respectively). In the subsequent two rounds, competition had been more active and the bid success rate had fallen to $18 \%$. Moreover, the preferred bid prices have fallen dramatically to $72 \%$ of the international LCOE benchmark and $66 \%$ of the price cap. These prices are highly competitive, not only in comparison to international prices, but also with respect to local coal-based electricity generation. It is estimated that by the time the round three projects are being implemented the weighted price of electricity from these investments will be $77 \%$ of the equivalent cost from new coal-based power stations.

This improvement in the outcomes of the REI4P bidding process is a reflection of the programme's attention to a broad range of factors that support competitive prices, including many of the key success factors identified in Section 2.4. South Africa's compliance with these factors has already been detailed in Table 2 and the generally high rate of compliance augurs well for the future of REI4P. For instance, the bidding process was clearly communicated with the extensive bid documents covering in detail many aspects including quotas in respect of technologies; price caps in $\mathrm{R} / \mathrm{kWh}$ for each technology; requirements for local content, job creation and socio-economic development; cap on foreign exchange exposure; allowable inflation clauses; evaluation process and scoring template (see for example documents from the Department of Energy [38, 45]. Moreover, it is apparent that the template and the evaluation process are closely aligned to the overall objectives. 
Unfortunately it is not possible to establish at this point the extent to which the REI4P's objectives are being realised. Although the national Department of Energy has implemented a detailed monitoring and evaluation process, none of this information is publicly available, making it difficult for independent researchers to assess the programme's effectiveness in several of its key area. Even in the absence of this information, other studies have noted a few early problems including:

- limited competition in round one and hence the high procurement prices relative to international benchmarks [37];

- manipulation of the local content formula by importers and hence the low probability that the programme will achieve its targets with respect to job creation and manufacturing (see Section 3.4) [19];

- high transaction costs and lack of suitably qualified transaction advisors to fulfil the contractual requirements of the procurement process [37]; and

- difficulty in achieving a balance between the promotion of economic development and electricity prices, and hence the need to re-calibrate the 70:30 model, where the latter refers to the adjudication points which are allocated on the basis of $70 \%$ price and $30 \%$ socio-economic development [45].

Despite the progress in round three, the present situation is still disappointing in respect of localisation. Some companies have established manufacturing facilities, yet have failed to see any orders from the independent power producers and have or are considering closing these facilities. An alternative means of both establishing local manufacturing and job creation targets, and monitoring compliance with these targets, is required. Several possibilities exist including the use of 'jobs per $\mathrm{MW}^{\prime}$ ' as the localisation indicator, or higher local content targets (these have already been increased for future rounds), or more detailed targets in certain specific areas including PV module assembly, wind turbine support towers and blades, and other components.

\section{Conclusions and Policy Implications}

South Africa's REI4P has been a successful initiative in several respects, including the diversification of the power generation sector from a single to 64 power producers in the first three rounds only, a more rapid response to its energy crisis than would have otherwise been possible, and the procurement of electricity at competitive prices, even relative to the present grid prices, with the exception of the first bidding round which was characterised by a general lack of competition and high prices. Indeed, the predictions of this study have shown that the REI4P cost of electricity will reach parity with the cost of new coal-based generation by 2016 and thereafter will be lower than the LCOE of either coal or nuclear power. This is an important and highly significant result, and suggests that the continued inclusion of non-economic options in South Africa's energy policy, such as coal-based power and nuclear technology, requires urgent revision.

In addition to the energy mix, there are several other areas in which the REI4P could be improved in order to ensure that its overall socio-economic targets can be met, and its impact can be increased. These areas include a revision of the local content requirements to increase inward investment and technology transfer for local manufacturing; additional 
stimulation of local research and development; and increased transparency in terms of monitoring and evaluation to ensure greater public scrutiny of the programme's benefits. The revision of the local content requirements in particular is considered to be an important requirement given evidence of its limited impact to date and some manipulation of the system by local REI4P bidders.

Finally, the high capital investment characteristic of renewable energy projects means that over time such projects will compete primarily on a cost of capital basis. Bidders with access to 'balance sheet' funding will have a significant advantage due to being able to bid using $\mathrm{P}_{50}$ as opposed to $\mathrm{P}_{90}$ factors and will dominate in the bidding process. Although the first two rounds of the REI4P have been successful at bringing new, smaller companies into the power generation sector, in the subsequent rounds it is likely that the bigger companies will be more successful. If this outcome is to be avoided the adjudication process will need to be revised in order to include additional measures that will favour small bidders, such as ringfencing for such bidders a portion of the total allocation.

\section{Acknowledgements}

The authors gratefully acknowledge the willingness of Mr Michael Mulcahy of GreenCape to share his research report and allow the use of his data in this publication. The article has also benefitted from the informative discussions with Dr Francois du Plessis of GreenCape and several students including Mr Adedeji Adeyemo and Mr Tapiwa Hondova.

\section{References}

[1] Department of Energy. Integrated Resource Plan for Electricity 2010-2030, Revision 2, Final Report. Pretoria: Department of Energy; 2011.

[2] Batchelor P, Dunne P. Industrial participation, investment and growth: the case of South Africa's defence-related industry. Development Southern Africa. 2000;17:417-35.

[3] Van Dyk JJ. An evaluation of the South African Department of Defence's policy on Defence Industrial Participation (DIP) as a defence industrial development mechanism [submitted in fulfillment of the requirements for the degree Magister Artium in the Faculty of Development Studies]. Port Elizabeth: Nelson Mandela Metropolitan University; 2008.

[4] Ramo JC. The Beijing Consensus: Foreign Policy Centre London; 2004.

[5] Feldman D, Barbose G, Margolis R, Wiser R, Darghouth N, Goodrich A. Photovoltaic Pricing Trends: Historical, Recent, and Near-Term Projections. National Renewable Energy Laboratory (NREL), Golden, CO.; 2012.

[6] Kost C, Schlegl T, Thomsen J, Nold S, Meyer J. Levelized Cost of Electricity Renewable Energies. 2012.

[7] Department of Energy and Climate Change. Electricity Generation Costs. In: Department of Energy and Climate Change, editor. Washington; 2012. 
[8] IRENA. Renewable Power Generation Costs in 2012: An Overview. Bonn: International Renewable Energy Agency (IRENA); 2013.

[9] IRENA. Summary for Policy Makers: Renewable Power Generation Costs. Bonn: International Renewable Energy Agency (IRENA); 2012.

[10] De la Tour A, Glachant M, Meniere Y. Predicting the costs of photovoltaic solar modules in 2020 using experience curve models. Energy. 2013;62:341 - 8.

[11] Swanson RM. A vision for crystalline silicon photovoltaics. Progress in photovoltaics: Research and Applications. 2006;14:443-53.

[12] Schilling MA, Esmundo M. Technology S-curves in renewable energy alternatives: Analysis and implications for industry and government. Energy Policy. 2009;37:1767-81.

[13] Winkler $\mathrm{H}$, Hughes $\mathrm{A}$, Haw M. Technology learning for renewable energy: Implications for South Africa's long-term mitigation scenarios. Energy Policy. 2009;37:4987-96.

[14] Nemet GF. Interim monitoring of cost dynamics for publicly supported energy technologies. Energy Policy. 2009;37:825-35.

[15] Raugei M, Frankl P. Life cycle impacts and costs of photovoltaic systems: current state of the art and future outlooks. Energy. 2009;34:392-9.

[16] Sawin J. National policy instruments: Policy lessons for the advancement \& diffusion of renewable energy technologies around the world. In: Assmann D, Laumanns U, Uh D, editors. Renewable Energy: A Global Review of Technologies, Policies and Markets. London: Earthscan; 2006.

[17] REN21. Renewables 2013: Global Status Report. Paris: REN21; 2013.

[18] Ban-Weiss G, Larsen D, Li SX, Wilusz D. Job Creation Studies in California for Vote Solar. Berkeley: University of California; 2004.

[19] Mulcahy M. Review of the Competitive Bid for PV in South Africa; is SA Maximising Job Creation and Value for Money from Its Photovoltaic Industry? [Research paper presented in partial fulfilment of the requirements for the Masters of Development Finance]. Cape Town: University of Cape Town; 2012.

[20] Kirkegaard JF, Hanemann T, Weischer L, Miller M. Toward a sunny future? Global integration in the solar PV industry. Peterson Institute for International Economics Working Paper. 2010.

[21] Lewis Jl, Wiser RH. Fostering a renewable energy technology industry: An international comparison of wind industry policy support mechanisms. Energy Policy. 2007;35:1844-57.

[22] Nemet GF. Demand-pull, technology-push, and government-led incentives for nonincremental technical change. Research Policy. 2009;38:700-9. 
[23] Haffajee Y. South Africa's Renewable Energy Policies; Renewable Energy IPP Program. Presentation to IRENA. Abu Dhabi; 2013.

[24] Seymore R, Inglesi-Lotz R, Blignaut J. A greenhouse gas emissions inventory for South Africa: A comparative analysis. Renewable and Sustainable Energy Reviews. 2014;34:371-9.

[25] Donev G, van Sark WG, Blok K, Dintchev O. Solar water heating potential in South Africa in dynamic energy market conditions. Renewable and Sustainable Energy Reviews. 2012;16:3002-13.

[26] Mohammed $Y$, Mustafa M, Bashir N. Status of renewable energy consumption and developmental challenges in Sub-Sahara Africa. Renewable and Sustainable Energy Reviews. 2013;27:453-63.

[27] Mohammed Y, Mustafa M, Bashir N, Mokhtar A. Renewable energy resources for distributed power generation in Nigeria: a review of the potential. Renewable and Sustainable Energy Reviews. 2013;22:257-68.

[28] Kadir A, Abidin MZ, Rafeeu Y, Adam NM. Prospective scenarios for the full solar energy development in Malaysia. Renewable and Sustainable Energy Reviews. 2010;14:3023-31.

[29] Shrimali G, Rohra S. India's solar mission: A review. Renewable and Sustainable Energy Reviews. 2012;16:6317-32.

[30] Stambouli AB, Khiat Z, Flazi S, Kitamura Y. A review on the renewable energy development in Algeria: Current perspective, energy scenario and sustainability issues. Renewable and Sustainable Energy Reviews. 2012;16:4445-60.

[31] Scholz R, Beckmann M, Pieper C, Muster M, Weber R. Considerations on providing the energy needs using exclusively renewable sources: Energiewende in Germany. Renewable and Sustainable Energy Reviews. 2014;35:109-25.

[32] Tsoutsos T, Papadopoulou E, Katsiri A, Papadopoulos AM. Supporting schemes for renewable energy sources and their impact on reducing the emissions of greenhouse gases in Greece. Renewable and Sustainable Energy Reviews. 2008;12:1767-88.

[33] Chang J, Leung DY, Wu C, Yuan Z. A review on the energy production, consumption, and prospect of renewable energy in China. Renewable and Sustainable Energy Reviews. 2003;7:453-68.

[34] Peidong Z, Yanli Y, Yonghong Z, Lisheng W, Xinrong L. Opportunities and challenges for renewable energy policy in China. Renewable and Sustainable Energy Reviews. 2009;13:43949.

[35] Ahmad S, Kadir MZAA, Shafie S. Current perspective of the renewable energy development in Malaysia. Renewable and Sustainable Energy Reviews. 2011;15:897-904.

[36] Becker B, Fischer D. Promoting renewable electricity generation in emerging economies. Energy Policy. 2013;56:446-55. 
[37] Eberhard A. Feed-In Tariffs or Auctions? Procuring Energy Supply in South Africa. Viewpoint. Washington: The World Bank Group; 2013.

[38] Department of Energy. Request for Qualification and Proposals for New Generation Capacity under the IPP Procurement Programme. Volume 4: Financial Requirements. In: Department of Energy, editor. Pretoria; 2011.

[39] South African Institute of Race Relations (SAIRR). South Africa Survey: 2012. Johannesburg: South African Institute of Race Relations (SAIRR); 2012.

[40] National Planning Commission. National Development Plan 2030: Our Future - Make it Work. Pretoria: The Presidency, Republic of South Africa; 2011.

[41] Tsikata M, Sebitosi A. Struggling to wean a society away from a century-old legacy of coal based power: Challenges and possibilities for South African Electric supply future. Energy. 2010;35:1281-8.

[42] Green Rhino Energy. Annual Solar Irradiance, Intermittency and Annual Variations. 2013.

[43] South African Bureau of Standards (SABS). Local Goods, Services and Works Measurement and Verification of Local Content. In: SABS Standards Division, editor. Pretoria: South African Bureau of Standards; 2011.

[44] Department of Energy. Bid Window 3; Preferred Bidders' Announcement. In: Department of Energy, editor. Pretoria; 2013.

[45] Department of Energy. Request for Qualification and Proposals for New Generation Capacity under the IPP Procurement Programme. Volume 5: Economic Development Requirements. Tender No: DOE/001/2011/2012. In: Department of Energy, editor. Pretoria. ; 2011.

[46] U.S. Energy Information Administration. 2018 Levelized Cost of New Generation Resources in the Annual Energy Outlook 2013. 2013.

[47] IRENA. Renewable Energy Innovation Policy: Success Criteria and Strategies. IRENA Working Paper. Bonn: International Renewable Energy Agency (IRENA); 2013.

[48] PVInsights. Solar PV Wafer Weekly Spot Price. PVInsights; 2013.

[49] National Energy Regulator of South Africa (NERSA). Revenue Application - Multi Year Price Determination 2013/14 to 2017/18 (MYPD3) By Eskom Holdings Soc Limited. Pretoria: NERSA; 2013.

[50] Wei M, Patadia S, Kammen DM. Putting renewables and energy efficiency to work: How many jobs can the clean energy industry generate in the US? Energy Policy. 2010;38:919-31.

[51] IRENA. Evaluating policies in support of the deployment of renewable power. Bonn: International Renewable Energy Agency (IRENA); 2012. 
[52] Eberhard A. Grid-Connected Renewable Energy in South Africa; Lessons on competitive tenders versus feed-in tariffs.: International Finance Corporation; 2013.

[53] U.S. Energy Information Administration. Levelized Cost of New Generation Resources in the Annual Energy Outlook 2011. Energy Information Administration; 2011. 
Appendix. Steps and Associated Costs in the Submission of a REI4P Bid

\begin{tabular}{|c|c|c|c|c|c|}
\hline Step & Activity & $\begin{array}{l}\text { Duration } \\
\text { (years) }\end{array}$ & Description & $\begin{array}{l}\text { Developer } \\
\text { Cost (R's) }\end{array}$ & Comments \\
\hline \multirow[t]{2}{*}{ One } & \multirow[t]{2}{*}{ Site Selection } & \multirow[t]{2}{*}{$\begin{array}{l}1 \text { to } 3 \\
\text { years }\end{array}$} & Site selection & $\begin{array}{l}\text { R0.5 to R1 } \\
\text { million }\end{array}$ & $\begin{array}{l}\text { Involves identification of suitable sites, collection of site specific climatic data and final } \\
\text { site selection. Wind and CSP projects require } 2 \text { years of climatic data; PV plants can } \\
\text { submit NASA irradiation data. }\end{array}$ \\
\hline & & & Agreement with landowner & $\begin{array}{l}\text { R50,000 to } \\
\text { R0.25 million }\end{array}$ & Some landowners request initial options payment. \\
\hline Two & $\begin{array}{l}\text { Environmental } \\
\text { Impact Assessment }\end{array}$ & 1 year & Completion of required EIA & $\begin{array}{l}\text { R0.5 to R1 } \\
\text { million }\end{array}$ & A study is required for each site. \\
\hline Three & $\begin{array}{l}\text { Preparation of bid } \\
\text { documents }\end{array}$ & 6 months & $\begin{array}{l}\text { Securing of black business and } \\
\text { financial partners }\end{array}$ & R2.5 million & $\begin{array}{l}\text { Extensive legal contracts are required at this stage requiring inputs from lender's legal } \\
\text { adviser, the lender's technical adviser, accounting adviser, insurance agents and the } \\
\text { 'equator principle' audit team. }\end{array}$ \\
\hline Four & Bid Bond & 2 months & $\begin{array}{l}\text { Submission of the first bid } \\
\text { bond }\end{array}$ & $\begin{array}{l}\text { R100,000 per } \\
\text { MW }\end{array}$ & The bid bond is a refundable deposit payable upon submission of the bid documents. \\
\hline Five & $\begin{array}{l}\text { Award as } \\
\text { Preferential Bidder }\end{array}$ & $\begin{array}{l}6 \text { months } \\
\text { to } 1 \text { year }\end{array}$ & $\begin{array}{l}\text { Adjudication of the bids by the } \\
\text { Department of Energy and } \\
\text { National Treasury }\end{array}$ & $\begin{array}{l}\text { No additional } \\
\text { funding }\end{array}$ & $\begin{array}{l}\text { Time delay can cause additional interest charges if any of the development expenses have } \\
\text { been funded with interest-bearing loans. }\end{array}$ \\
\hline \multirow{2}{*}{ Six } & \multirow{2}{*}{ Financial Close } & \multirow{2}{*}{3 months } & Submission of second bid bond & $\begin{array}{l}\text { R100,000 per } \\
\text { MW }\end{array}$ & $\begin{array}{l}\text { This bond is required for financial close and is refundable to the developer after the } \\
\text { signing of documents with the DOE. In reality these expenses are never incurred as they } \\
\text { are only invoiced (not paid) at financial close. }\end{array}$ \\
\hline & & & $\begin{array}{l}\text { Preparation of financial close } \\
\text { and power purchase } \\
\text { agreements }\end{array}$ & R6 million & $\begin{array}{l}\text { Estimate of the costs of the lender's legal adviser, the lender's technical adviser and } \\
\text { developer's legal advisor to compile the documents for financial close. }\end{array}$ \\
\hline Seven & $\begin{array}{l}\text { Signature of the EPC } \\
\text { Contract }\end{array}$ & 3 months & $\begin{array}{l}\text { The EPC contract usually } \\
\text { stipulates an initial payment of } \\
10 \%-15 \% \text { of the total cost }\end{array}$ & $\begin{array}{l}15 \% \text { of total } \\
\text { contract }\end{array}$ & $\begin{array}{l}\text { Engineering, Procurement and Construction (EPC) contractor is required to submit a } \\
\text { performance fee with the Department of Energy ( } 15 \% \text { of total contract); may be covered } \\
\text { by a performance bond. }\end{array}$ \\
\hline Eight & $\begin{array}{l}\text { Construction and } \\
\text { Commissioning }\end{array}$ & $\begin{array}{l}1 \text { to } 2 \\
\text { years }\end{array}$ & $\begin{array}{l}\text { Construction and } \\
\text { commissioning of the } \\
\text { generation plant }\end{array}$ & $\begin{array}{l}85 \% \text { of EPC } \\
\text { contract }\end{array}$ & $\begin{array}{l}\text { Project may incur delays if there are problems with international procurement or lack of } \\
\text { clarity on scope of services/tie-ins to the national grid. }\end{array}$ \\
\hline Nine & Operations & 20 years & $\begin{array}{l}\text { Generation and sale of power } \\
\text { to Eskom as per the supply } \\
\text { agreements }\end{array}$ & $\begin{array}{l}\text { Revenue as per } \\
\text { the supply } \\
\text { agreement }\end{array}$ & $\begin{array}{l}\text { Revenues are guaranteed over a } 20 \text { year period on an inflated basis (CPIX), depending on } \\
\text { the supply agreement. The rate of return is specific to each agreement but would } \\
\text { typically be about } 18 \% \text { based on the energy regulator's guidelines in respect of a 'fair rate } \\
\text { of return'. }\end{array}$ \\
\hline
\end{tabular}

Source: Department of Energy [45] 